\title{
Phellinins A1 and A2, new styrylpyrones from the culture broth of Phellinus sp. KACC93057P: I. Fermentation, taxonomy, isolation and biological properties
}

\author{
In-Kyoung Lee ${ }^{1}$, Geon-Sik Seo ${ }^{2}$, Nak Beom Jeon ${ }^{3}$, Hee-Wan Kang ${ }^{4}$ and Bong-Sik Yun ${ }^{1}$
}

Novel styrylpyrones, phellinins A1 and A2, were isolated together with known styrylpyrone compounds, hispidin and 1,1distyrylpyrylethan, from the cultured broth of Phellinus sp. KACC93057P. These compounds were purified by solvent partition, Sephadex LH-20 column chromatography, $\mathrm{C}_{18}$-solid phase extraction and finally by reversed-phase (ODS) TLC. To identify the phellinin producer Phellinus sp. KACC93057P, the ribosomal DNA (rDNA) internal transcribed space regions containing 5.8 rDNA were sequenced and compared with those of the known Phellinus isolates. Phellinus sp. KACC93057P was $94.8 \%$ identical to $P$. baumii and $P$. linteus, all of which did not produce phellinins $A 1$ and $A 2$. These compounds significantly scavenged free radicals such as 1,1-diphenyl-2-picrylhydrazyl, 2,2'-azinobis-(3-ethylbenzothiazoline-6-sulfonic acid) and superoxide.

The Journal of Antibiotics (2009) 62, 631-634; doi:10.1038/ja.2009.82; published online 28 August 2009

Keywords: free radical scavenger; fungal metabolite; Phellinus sp. KACC93057P; phellinins A1 and A2; styrylpyrone

\section{INTRODUCTION}

Several mushrooms including the genera Phellinus and Inonotus are used as traditional medicines and produce natural pigments, styrylpyrones, which have important roles in their biological activity. The pharmacological activities of styrylpyrones isolated from mushrooms, including antioxidant, anti-inflammation, anticancer and anti-platelet aggregation activities, have been reported. ${ }^{1-3}$ To date, a number of styrylpyrone metabolites have been isolated from Phellinus and Inonotus, ${ }^{4-6}$ and the metabolites from the fruiting body were more complex and had greater structural diversity when compared with metabolites isolated from mycelial culture. ${ }^{7}$ It is known that the fungal ligninolytic enzymes, laccase and peroxidase, catalyze the polymerization of styrylpyrone monomers and transformation of many phenolic compounds into polymeric structures. ${ }^{8,9}$

In a continuous search for novel styrylpyrones from the cultured broths of Phellinus isolates, we found that Phellinus sp. KACC93057P produced novel free radical scavengers, phellinins A1 and A2 (1, Figure 1), together with the known compounds, hispidin (2) and 1,1distyrylpyrylethan (3). Compound $\mathbf{1}$ was obtained as an inseparable mixture of isomers (A1 and A2) with the same ratio. In this study, the identification and fermentation of the microorganism Phellinus sp.
KACC93057P and the isolation and antioxidant activity of $\mathbf{1}$ are described. The physicochemical properties and structure determination of 1 will be described in an accompanying study. ${ }^{10}$

\section{RESULTS}

HPLC analysis of styrylpyrones

It is known that ethyl acetate extracts of the cultured broths of the medicinal fungi Inonotus xeranticus and P. linteus show potent antioxidant activity because of the presence of styrylpyrones. ${ }^{7}$ To identify novel antioxidant styrylpyrones from Phellinus spp. isolates, the ethyl acetate layer of four cultured broths was analyzed by reversed-phase HPLC equipped with a photodiode array detector. The styrylpyrones showed characteristic UV absorption maxima at 380-420 and 245$255 \mathrm{~nm}$. In general, both hispidin and its dimmers, hypholomine B, 3,14'-bihispidinyl and 1,1-distyrylpyrylethan, are found in the genera Phellinus and Inonotus. ${ }^{711}$ The constituents and content of styrylpyrones from Phellinus spp. 52370, 52387 and 52391 and I. xeranticus BS064 were similar on the basis of their HPLC profiles (Figure 2). The phellinus sp. KACC93057P, however, had a different HPLC profile in which the peaks corresponding to hypholomine B and 3,14'-bihispidinyl seemed relatively small and several unidentified peaks were

\footnotetext{
${ }^{1}$ Division of Biotechnology, College of Environmental and Bioresource Sciences, Chonbuk National University, Iksan, Jeonbuk, Korea; ${ }^{2}$ Korea National Agriculture College, Hwaseong, Kyonggi, Korea; ${ }^{3}$ Incheon International Airport Branch, National Plant Quarantine Service, Seoul, Korea and ${ }^{4}$ Graduate School of Biotechnology and Information Technology, Hankyong National University, Ansung, Kyonggi, Korea

Correspondence: Professor H-W Kang, Graduate School of Biotechnology and Information Technology, Hankyong National University, Ansung, Kyonggi 456-749, Korea and Professor B-S Yun, Division of Biotechnology, College of Environmental and Bioresource Sciences, Chonbuk National University, Iksan, Jeonbuk 570-752, Korea. E-mail: bsyun@chonbuk.ac.kr
}

Received 29 June 2009; revised 20 July 2009; accepted 27 July 2009; published online 28 August 2009 
<smiles>C=C1CCCC(C)(C)[C@@H]1CC[C@]1(C)C=Cc2c(cc(/C=C/c3ccc(O)c(O)c3)oc2=O)O1</smiles>

Phellinin A1<smiles>C=C1CCCC(C)(C)C1CCC1(C)C=Cc2c(cc(/C=C/c3ccc(O)c(O)c3)oc2=O)O1</smiles>

Phellinin A2

1<smiles>O=c1cc(O)cc(/C=C/c2ccc(O)c(O)c2)o1</smiles>

2<smiles>CC(c1c(O)cc(/C=C/c2ccc(O)c(O)c2)oc1=O)c1c(O)cc(/C=C/c2ccc(O)c(O)c2)oc1=O</smiles><smiles>O=c1cc(O)cc(/C=C/c2cc(O)c(O)cc2-c2c(O)cc(/C=C/c3ccc(O)c(O)c3)oc2=O)o1</smiles><smiles>O=c1cc(O)cc(C2c3c(cc(/C=C/c4ccc(O)c(O)c4)oc3=O)OC2c2ccc(O)c(O)c2)o1</smiles>

Figure 1 Structures of phellinins A1 and A2 (1), hispidin (2), 1,1-distyrylpyrylethan (3), 3,14'-bihispidinyl (4), hypholomine B (5).

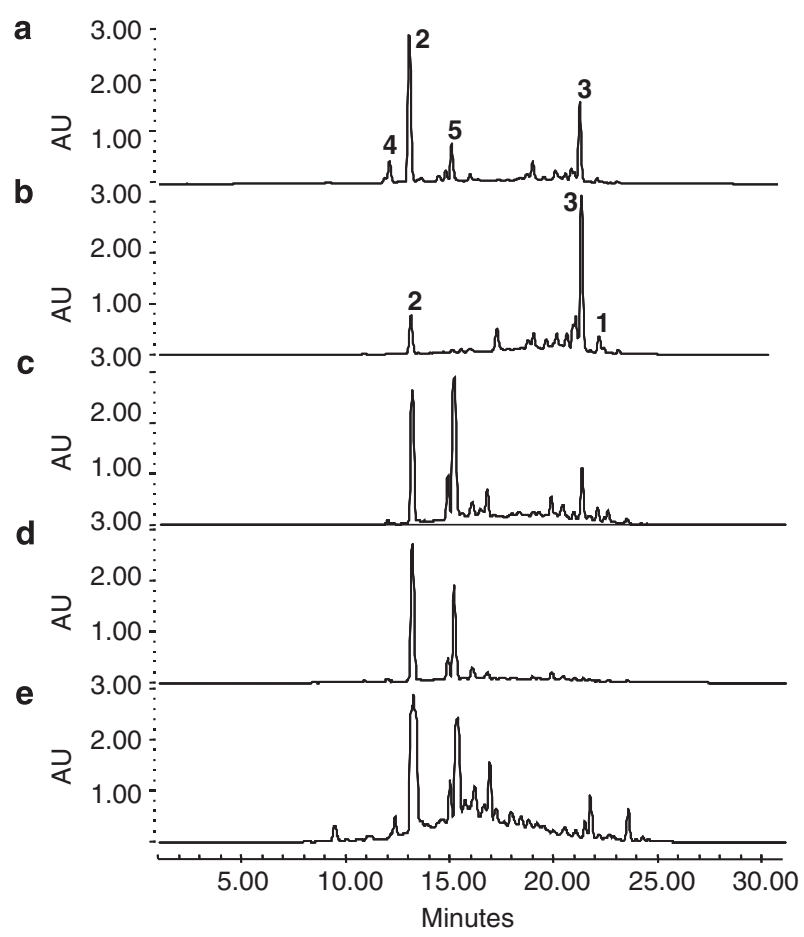

Figure 2 HPLC chromatograms of the ethyl acetate layer of cultured broths of Inonotus xeranticus BS064 (a), Phellinus sp. KACC93057P (b), Phellinus sp. 52387 (c), Phellinus sp. 52391 (d), Phellinus sp. 52370 (e) strains. The elution profile was established by monitoring UV absorbance at $380 \mathrm{~nm} .1$ phellinins $A 1$ and A2; 2 hispidin; 3 1,1-distyrylpyrylethan; 4 3,14'-bihispidinyl; 5 hypholomine B. observed. To identify these new peaks, the fungus phellinus sp. KACC93057P was mass cultured.

\section{Taxonomy of Phellinus sp. KACC93057P}

Nuclear ribosomal DNA (rDNA) has been used to analyze major evolutionary events. This is especially true for the internal transcribed space (ITS) region, which has been established as a useful tool for identifying fungi at the species level. Thus, rDNA ITS regions containing 5.8 rDNA were sequenced to investigate the genetic relatedness among Phellinus spp. Alignment of these ITS sequences revealed a close genetic relationship among P. baumii and P. linteus, and Phellinus sp. KACC93057P was found to be $94.8 \%$ identical to P. baumii and P. linteus (Figure 3).

Therefore, the morphological and physiological characteristics of Phellinus sp. KACC93057P were compared with P. baumii and $P$. linteus. The mycelial growth of Phellinus sp. KACC93057P was excellent on YGM broth, which grew more than twice as fast as the other strains of Phellinus spp. In addition, KACC93057P had a mycelial colony color of bright yellow and abundant aerial mycelium on potato dextrose agar (PDA) media that was distinguishable from P. baumii and $P$. linteus (Figure 4). Earlier, a specific PCR primer set with PLSPF2 (5'-ACTTATTCCATCGCAGGTTA-3') and PLSPR1 (5'CTCGTACCTCGTCATCAAGT- $3^{\prime}$ ) was developed for differentiating P. linteus from other closely related Phellinus spp. ${ }^{12}$ However, the primer set did not produce PCR amplicon from genomic DNA of Phellinus sp. KACC93057P, indicating that at least KACC93057P was not $P$. linteus. In conclusion, Phellinus sp. KACC93057P is likely a variant in the $P$. linteus complex and could also not be excluded from the novel Phellinus species in morphological and physiological difference, ITS rDNA data and PCR detection. 


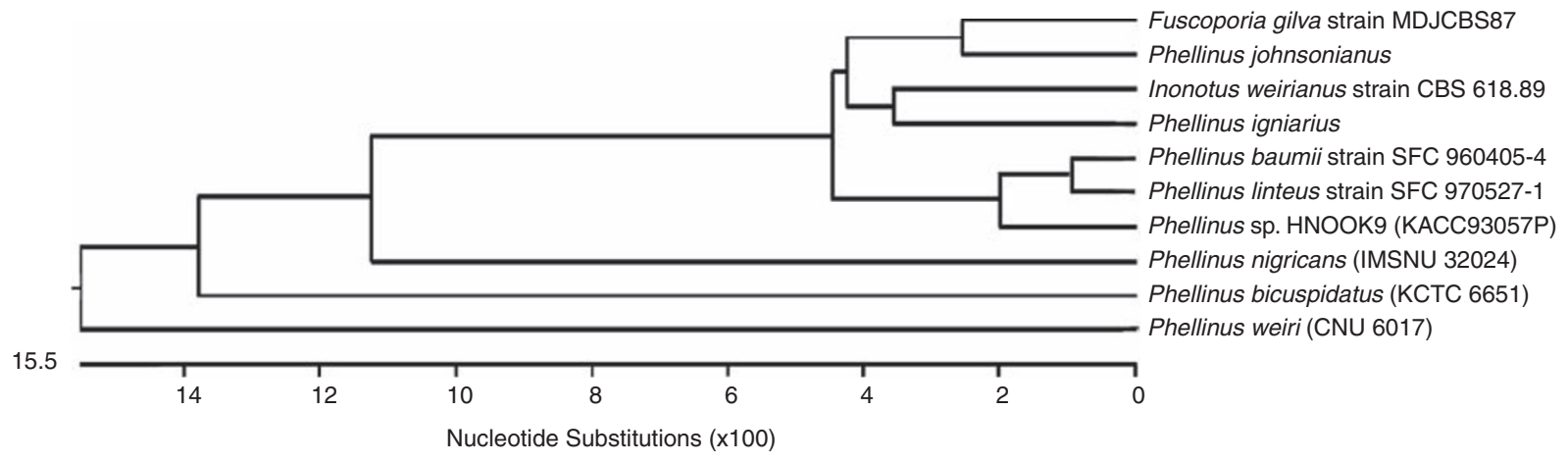

Figure 3 Genetic relationship of Phellinus sp. KACC93057P based on rDNA ITS sequences.

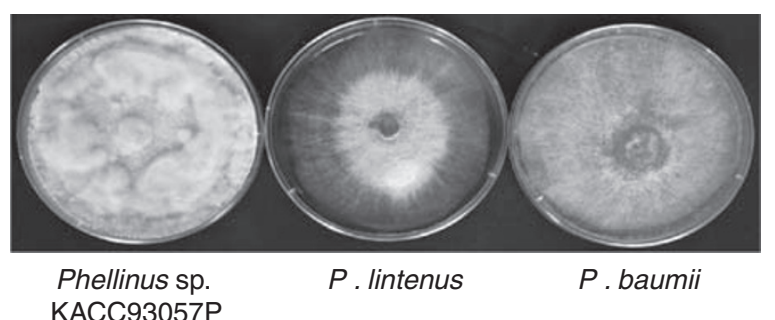

Figure 4 Morphological characteristics of mycelial mats of Phellinus sp. KACC93057P, P. baumii and P. linteus on PDA media after 14 days of culture.

\section{Isolation and purification}

The procedure used for isolating the styrylpyrones to assess their antioxidant activity was summarized in Figure 5. In total, 21 of culture broth was filtered to separate the broth filtrate and the mycelium. Mycelium was extracted with 0.51 of $80 \%$ acetone. The acetone extracts were filtered and the filtrate was evaporated under reduced pressure to remove acetone. The resulting residue was extracted with ethyl acetate twice and then subjected to Sephadex LH-20 (Pharmacia, Uppsala, Sweden) column chromatography using $\mathrm{MeOH}$ as the elution solvent. Using this approach, two active fractions were observed. One of the fractions was further purified by $\mathrm{C}_{18}$ Sep-Pak cartridge (Waters, Milford, MA, USA) extraction in which the eluting phase was a gradient of increasing methanol (40-90\%) in water. The active fraction, which eluted at $70-80 \%$ aqueous $\mathrm{MeOH}$, was purified on a column of Sephadex LH-20 with 70\% aqueous $\mathrm{MeOH}$, followed by reversed-phase (ODS) TLC developed with $90 \%$ aqueous $\mathrm{MeOH}$ to give $\mathbf{1}(2.5 \mathrm{mg})$. The other fraction was chromatographed on a Sephadex LH-20 column with $70 \%$ aqueous $\mathrm{MeOH}$, followed by reversed-phase TLC developed with $70 \%$ aqueous $\mathrm{MeOH}$ to give $2(3 \mathrm{mg})$ and $3(5 \mathrm{mg})$. Details of the structure of compound $\mathbf{1}$ will be presented in an accompanying paper.

\section{Free radical scavenging activity}

The main property of an antioxidant is its ability to scavenge free radicals. The free radical scavenging efficacies of 1-3 were evaluated using the 1,1-diphenyl-2-picrylhydrazyl (DPPH) radical, 2,2'-azinobis(3-ethylbenzothiazoline-6-sulfonic acid (ABTS) radical anion and superoxide radical cation scavenging assay methods. In the DPPH and ABTS radical scavenging activity assay, the results were expressed in terms of trolox equivalent antioxidant capacity $\left(\mathrm{IC}_{50}\right.$ of $\mu \mathrm{M}$ compound per $\mathrm{IC}_{50}$ of $\mu \mathrm{M}$ trolox). Results from the free radical scavenging assay are presented in Table 1, in which all the compounds were capable of scavenging DPPH, ABTS and superoxide radicals, in a concentration-dependent manner and all of the tested compounds showed potent activity comparable with the positive control, caffeic acid and butylated hydroxyanisole (BHA).

\section{METHODS}

Fungi and fermentation

To search novel antioxidant styrylpyrones from Phellinus spp., the fungal strains (52387, 52391 and 52370) of Phellinus sp. were obtained from the Rural Development Administration in Korea, and the strain of Phellinus sp. KACC93057P was obtained by tissue culture from the fruiting body of an unidentified fungus belonging to Phellinus sp. In brief, a small piece of fresh mushroom was incubated on a Petri dish containing PDA medium. After incubation at $28^{\circ} \mathrm{C}$ for 5 days, the mycelium grown was used to obtain axenic culture of Phellinus sp. KACC93057P.

For analysis of the styrylpyrone isolated from cultured broths, three strains of Phellinus were grown in potato dextrose broth medium at $28^{\circ} \mathrm{C}$ for 10 days and a strain of Phellinus sp. KACC93057P was cultured in stationary position at $25^{\circ} \mathrm{C}$ for 14 days in tissue culture bottle $(500 \mathrm{ml}$ with $200 \mu \mathrm{m}$ filter cap) and containing $120 \mathrm{ml}$ of YGM medium (yeast extract $1 \%$, glucose $0.4 \%$ and malt extract $0.4 \%$ ). The morphological and cultural characteristics were investigated using PDA medium at $25^{\circ} \mathrm{C}$ for 14 days.

\section{HPLC analysis of styrylpyrones}

The styrylpyrone constituents in the cultured broths were detected using a method reported earlier. ${ }^{7}$ In brief, the ethyl acetate layer of the cultured broths of fungi Phellinus spp. was analyzed by analytical reversed-phase HPLC (Hitachi L-2000 series, Hitachi, Tokyo, Japan), which consisted of an autosampler, a pump, a photodiode array detector and a reversed-phase $\mathrm{C}_{18}$ column $\left(150 \times 4.6 \mathrm{~mm}\right.$ i.d.; Cosmosil, Nacalai tesque, Kyoto, Japan) ${ }^{6} \mathrm{~A}$ linear gradient containing water acidified with $0.04 \%$ trifluoroacetic acid (vv) and methanol was used at a flow rate of $1 \mathrm{ml} \mathrm{min}^{-1}$. HPLC detection was initiated with a $5 \mathrm{~min}$ flow at $30 \%$ methanol, which reached $90 \%$ methanol within $23 \mathrm{~min}$. The column was washed with $90 \%$ methanol for $3 \mathrm{~min}$ and then equilibrated at $30 \%$ methanol for $4 \mathrm{~min}$.

\section{ITS rDNA analysis}

Genomic DNA of Phellinus sp. KACC93057P grown in malt-yeast broth (2\% malt extract and $0.2 \%$ yeast extract) was extracted as described by Graham et al. ${ }^{13}$ A total of $200 \mathrm{mg}$ of mycelia were transferred to a $1.5 \mathrm{ml}$ test tube and $400 \mu \mathrm{l}$ of lysis buffer ( $200 \mathrm{~mm}$ Tris- $\mathrm{HCl}$ ( $\mathrm{pH} 8.0$ ), $100 \mathrm{~mm} \mathrm{NaCl}, 25 \mathrm{~mm}$ EDTA and $0.5 \% \mathrm{SDS})$ containing proteinase $\mathrm{K}(50 \mu \mathrm{g})$ was added to the tube. The tube was placed in a $65^{\circ} \mathrm{C}$ water bath for $15 \mathrm{~min}$ and then extracted with chloroformisoamyl alcohol (24:1, v/v) and centrifuged at 12000 r.p.m. for $10 \mathrm{~min}$. The upper phase was transferred to a new tube and DNA was precipitated with a 0.7 volume of isopropanol, washed with $70 \%$ ethanol, dried and resuspended in $50 \mu \mathrm{l}$ of TE buffer (10 mm Tris-HCl and $1 \mathrm{~m}$ EDTA, pH 8.0). The rDNA regions, including ITS 1,2 and the $5.8 \mathrm{~S}$ ribosomal gene, were amplified from the genomic DNA using the universal primers ITS 1 (5'-TCCGTAGGTGAACCTCGGC-3') and ITS 2 (5'-TCCTCCGCTTATTGATATGC- $\left.3^{\prime}\right) .{ }^{14}$ The PCR products containing the ITS region were purified using a Wizard PCR prep kit (Promega, Madison, WI, USA) and were directly sequenced with a BigDye terminator cycling sequencing kit (Applied Biosystem Inc, Foster City, CA, USA). The ITS sequences from Phellinus sp. KACC93057P of this study and different Phellinus spp. retrieved from GenBank were aligned using the MegAlign program of the DNA star software 


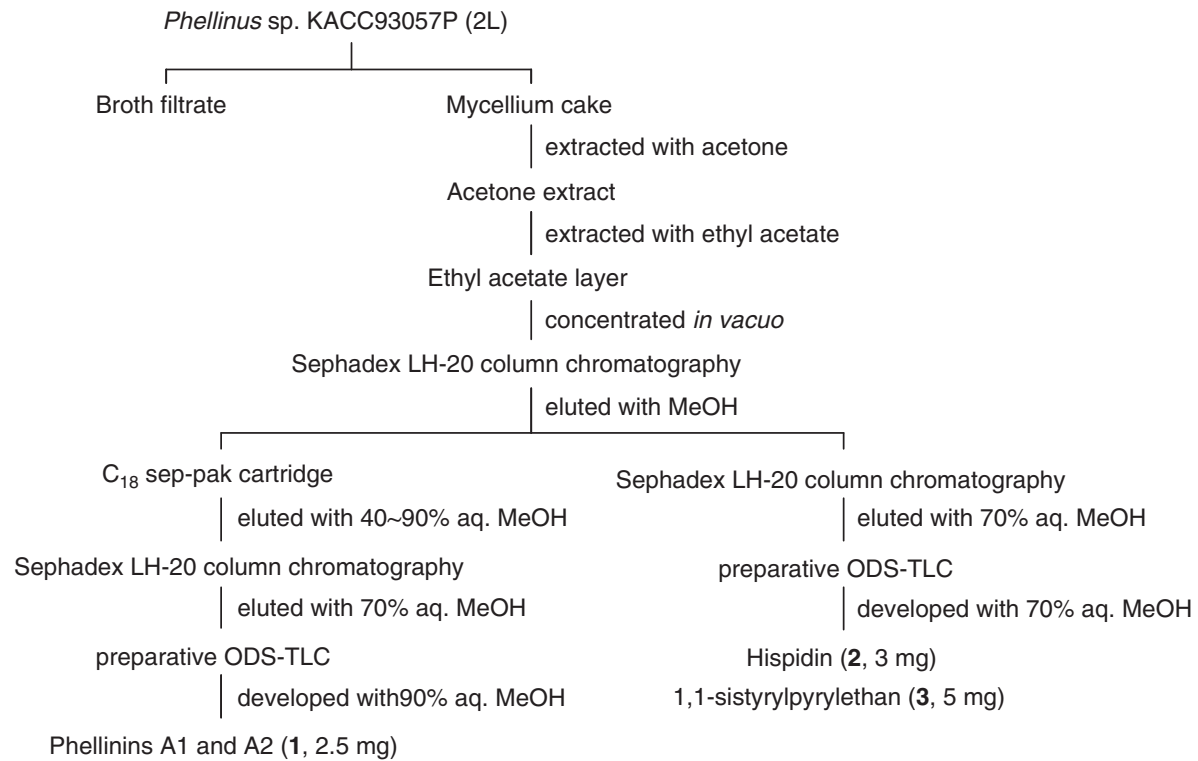

Figure 5 Isolation procedures of compounds $\mathbf{1 - 3}$.

Table 1 Free radical scavenging activity of the compounds isolated

\begin{tabular}{lccc}
\hline & \multicolumn{2}{c}{ TEAC $^{\mathrm{a}, \mathrm{b}}$} & \\
\cline { 2 - 3 } Compounds & DPPH & ABTS & Superoxide ${ }^{\mathrm{c}} / C_{50}(\mu \mathrm{M})^{\mathrm{b}}$ \\
\hline Phellinin A (1) & 0.76 & 0.47 & $47.3 \pm 3.3$ \\
Hispidin (2) & 1.31 & 2.27 & $34.9 \pm 4.0$ \\
1,1-distyrylpyrylethan (3) & 0.37 & 0.18 & $32.0 \pm 1.1$ \\
Caffeic acid & 0.11 & 0.18 & $16.5 \pm 2.3$ \\
BHA & 0.34 & 0.12 & $>500$ \\
\hline
\end{tabular}

Abbreviations: ABTS, 2,2'-azinobis-(3-ethylbenzothiazoline-6-sulfonic acid); BHA, butylated hydroxyanisole; DPPH, 1,1-diphenyl-2-picrylhydrazyl; TEAC, trolox equivalent antioxidant capacity.

aExpressed as $\mathrm{IC}_{50}$ of $\mu \mathrm{m}$ compound per $\mathrm{IC}_{50}$ of $\mu \mathrm{m}$ trolox.

bResults presented as the mean $(n=3) \pm$ s.d.

'Xanthine/xanthine oxidase.

(Madison, WI, USA). The phylogenic tree was constructed using the neighborjoining program of MEGA (Tempe, AZ, USA).

\section{Free radical scavenging activity assay}

The ability of the samples to scavenge free radical was determined using the DPPH radical, ABTS radical cation and superoxide radical anion scavenging assay methods. ${ }^{7}$ In detail, $5 \mu \mathrm{l}$ of each sample was combined with $95 \mu \mathrm{l}$ of $150 \mu \mathrm{M}$ methanolic DPPH in triplicate. After incubation at room temperature for $30 \mathrm{~min}$, the absorbance at $517 \mathrm{~nm}$ was read using a Molecular Devices Spectromax microplate reader (Sunnyvale, CA, USA).

The ABTS was dissolved in water to a concentration of $7 \mathrm{~mm}$. The ABTS cation radical was produced by reacting the ABTS stock solution with $2.45 \mathrm{~mm}$ potassium persulfate and by allowing the mixture to stand in the dark for $12 \mathrm{~h}$. After adding $95 \mu \mathrm{l}$ of the ABTS radical cation solution to $5 \mu \mathrm{l}$ of antioxidant compounds in methanol, the absorbance was measured by a microplate reader at $734 \mathrm{~nm}$ after mixing for up to $6 \mathrm{~min}$.

The superoxide radical anion scavenging activity was evaluated using the xanthine/xanthine oxidase method. In brief, each well of a 96-well plate contained $100 \mu \mathrm{l}$ of the following reagents: $50 \mathrm{~mm}$ potassium phosphate buffer ( $\mathrm{pH}$ 7.8), $1 \mathrm{~mm}$ EDTA, $0.04 \mathrm{~mm}$ NBT (nitroblue tetrazolium), $0.18 \mathrm{~mm}$ xanthine, $250 \mathrm{mU} \mathrm{ml}^{-1}$ xanthine oxidase and the sample at different concentrations. The reaction was incubated for $30 \mathrm{~min}$ at $37^{\circ} \mathrm{C}$ in the dark. The xanthine oxidase catalyzes the oxidation of xanthine to uric acid and superoxide, and the superoxide reduces NBT to blue formazan. The reduction of NBT to blue formazan was measured at $560 \mathrm{~nm}$ in a microplate reader. BHA, trolox and caffeic acid were used as a reference.

\section{ACKNOWLEDGEMENTS}

This work was supported by a grant (20080401-034-069) from the BioGreen 21 Program of the Rural Development Administration (RDA), Republic of Korea.

$1 \mathrm{Kim}, \mathrm{S}$. D. et al. The mechanism of anti-platelet activity of davallialactone: Involvement of intracellular calcium ions, extracellular signal-regulated kinase 2 and p38 mitogenactivated protein kinase. Eur. J. Pharmacol. 584, 361-367 (2008).

2 Lee, Y. G. et al. Src kinase-targeted anti-inflammatory activity of davallialactone from Inonotusxeranticus in lipopolysaccharide-activated RAW264.7 cells. Br. J. Pharmacol. 154, 852-863 (2008).

3 Lee, I. K. \& Yun, B. S. Highly oxygenated and unsaturated metabolites providing a diversity of hispidin class antioxidants in the medicinal mushrooms Inonotus and Phellinus. Bioorg. Med. Chem. 15, 3309-3314 (2007).

4 Lee, I. K. \& Yun, B. S. Hispidin analogs from the mushroom Inonotus xeranticus and their free radical scavenging activity. Bioorg. Med. Chem. Lett. 16, 2376-2379 (2007).

5 Lee, I. K., Kim, Y. S., Jang, Y. W., Jung, J. Y. \& Yun, B. S. New antioxidant polyphenols from the medicinal mushroom Inonotusobliquus. Bioorg. Med. Chem. Lett. 17, 66786681 (2007).

6 Lee, I. K., Seok, S. J., Kim, W. K. \& Yun, B. S. Hispidin derivatives from the mushroom Inonotus xeranticus and their antioxidant activity. J. Nat. Prod. 69, 299-301 (2006).

7 Jung, J. Y. et al. Antioxidant polyphenols from the mycelia culture of the medicinal fungi Inonotusxeranticus and Phellinuslinteus. J. Appl. Microbiol. 104, 1824-1832 (2008).

8 Ward, G., Hadar, Y., Bilkis, I., Konstantinovsky, L. \& Dosoretz, C. G. Initial steps of ferulic acid polymerization by lignin peroxidase. J. Biol. Chem. 276, 18734-18741 (2001).

9 Lee, I. K. \& Yun, B. S. Peroxidase-mediated formation of the fungal polyphenol 3,14'bihispidinyl. J. Microbiol. Biotechnol. 18, 107-109 (2008).

10 Lee, I. K., Jung, J. Y., Kim, Y. H. \& Yun, B. S. Phellinins A1 and A2, new styrylpyrones from the culture broth of Phellinus sp. KACC93057P: II. Physicochemical properties and structure elucidation. J. Antibiot. 62, 635-637 (2009).

11 Fiasson, J. L. Distribution of styrylpyrones in the basidiocarps of various Hymenochaetaceae. Biochem. Syst. Ecol. 10, 289-296 (1982).

12 Kang, H. W. et al. PCR based detection of Phellinus linteus using specific primers generated from universal rice primer (URP) derived PCR polymorphic band. Mycobiology 30, 202-207 (2002).

13 Graham, G. C., Mayer, S. P. \& Henry, R. J. Amplified method for the preparation of fungal genomic DNA for PCR and RAPD analysis. Biotechniques 16, 175-269 (1994).

14 Park, D. S. et al. PCR-based sensitive detection of wood decaying fungus Phellinuslinteus by specific primer from rDNA ITS regions. Mycobiology 29, 7-10 (2001). 